\title{
Kollegialitet, takstbruk og hvit løgn
}

\author{
Av og til oppstår det uenighet om pris når en legepraksis skal selges. Noen ganger \\ blir Legeforeningen involvert, noen ganger omtales slike saker også i mediene. \\ Som regel blir de involverte parter enige, men ikke alltid.
}

\author{
Ragnar Hotvedt \\ ragnar.hotvedt@uit.no \\ Rådet for legeetikk \\ Den norske legeforening \\ Postboks 1152 Sentrum \\ 0107 Oslo
}

Legeforeningen blir fra tid til annen involvert $i$ saker der det har oppstått uenighet om pris ved salg av en legepraksis. Slike saker har en tendens til å lokke frem mindre sympatiske sider ved oss. Saken dreier seg om overtakelse av en privat spesialistpraksis. Spesialist A ønsket å avslutte sin yrkeskarriere, og spesialist B ble av det regionale helseforetak tildelt en del av avtalehjemmelen. Uenigheten oppsto da det ble klart at dr. B ikke ønsket å betale dr. A det han forlangte for praksisen. Dr. B hevdet at praksisen var priset for høyt på grunn av langvarig takstmisbruk og trygdesvindel. Dr. A klaget dr. B inn for Rådet for legeetikk for hans påstander og bruk av journalarkiv.

\section{Redegjørelser}

Dr. B redegjorde for bakgrunnen for sine påstander. Han hadde tidligere vikariert i praksisen, og i forbindelse med dette mente han å ha påvist grovt trygdemisbruk. Blant annet hevdet han at det var sendt regninger til trygden for en spesiell undersøkelse som skulle være gjennomført på flere hundre pasienter, uten at resultatene av undersøkelsene var dokumentert i pasientenes journaler. Dr. B hadde drevet en form for «etterforskning» av dr. As praksis når det gjaldt bruk av takster, og han hevdet å ha funnet flere eksempler på takstmisbruk.

Dr. A hevdet på sin side at han hadde benyttet en «hvit løgn» overfor dr. B i forbindelse med vikariatene, idet han sa til dr. B at apparatet som ble benyttet ved den nevnte spesielle unders $ø$ kelse, var ute av drift. Men apparatet var ifølge dr. A egentlig helt $\mathrm{i}$ orden. Han hadde imidlertid låst det ned og derved hindret dr. $\mathrm{B} \mathrm{i}$ å bruke det, fordi bruken genererte utgifter til forbruksmateriell for dr. A. Dr. A hevdet også at han hadde låst ned resultatene av spesialundersøkelsene i et eget arkiv, utilgjengelig for vikarer.

Det oppsto en klagesak ved tildeling av hjemmelen. I forbindelse med dette sendte dr. B et brev til Helse- og omsorgsdepartementet, der han påsto at dr. A har drevet «en langvarig, systematisk, gjennomtenkt trygdesvindel». Han utdypet dette ved hjelp av flere eksempler. Dette førte til at departementet rettet en henvendelse til det regionale helseforetak, som igjen ba NAV undersøke om det var hold i påstanden om trygdemisbruk. Etter å ha gjennomgått saken konkluderte NAV med at de ikke hadde noen innvendinger til dr. As bruk av spesialundersøkelsen, og saken ble henlagt.

\section{Rådets uttalelse}

Rådet er kjent med at det fra tid til annen oppstår konflikter mellom kolleger om økonomiske forhold i forbindelse med overtakelse av avtalehjemler. Vanligvis løses disse i minnelighet. I den aktuelle saken har den økonomiske uenigheten bakgrunn $i$ at innklagede lege mener å ha oppdaget alvorlig og langvarig takstmisbruk hos klager. Innklagede lege har i meget liten grad tatt dette direkte opp med klager, og i stedet sendt brev direkte til Helseog omsorgsdepartementet.

Rådet mener at innklagede lege, dr. B, i denne saken har opptrådt kritikkverdig ved å bryte Etiske regler for leger Kap. II, $\S 1$ : «En lege skal vise kolleger og medarbeidere respekt og skal hjelpe, råde og veilede dem», og Kap. II, § 2, der det heter: «Dersom en lege oppdager tegn til faglig eller etisk svikt hos en kollega eller medarbeider, bør han/hun først ta dette opp med vedkommende» og «Hvis dette ikke fører frem, bør legen ta saken opp enten med administrativ overordnet, Dnlfs organer eller vedkommende helsemyndighet».

Rådet mener for øvrig at klageren, dr. A, har opptrådt kritikkverdig ved sin håndtering av resultatene av spesialundersøkelsene av pasienter. Dersom disse resultatene gjennom en årrekke holdes nedlåst $\mathrm{i}$ et eget arkiv, utilgjengelig for vikar, kan man ikke utelukke at dette vil kunne ha uheldige konsekvenser for pasienter. Rådet finner derfor å rette kritikk også mot klageren, dr. A, $i$ henhold til den samme bestemmelse i Kap. II, § 1: «En lege skal vise kolleger og medarbeidere respekt og skal hjelpe, råde og veilede dem.» Rådet finner at dr. A har opptrådt legeetisk kritikkverdig når han, som han selv skriver, både har løyet og holdt tilbake pasientdata for kollegaen, dr. B.

Oppgitte interessekonflikter: Ingen

Manuskriptet ble mottatt 11.11. 2009 og godkjent 17. 12. 2009. Medisinsk redaktør Petter Gjersvik. 